\title{
Case Report \\ Case Study of Expected Loss Failure Mode and Effect Analysis Model Based on Maintenance Data
}

\author{
Seungsik Min ${ }^{1}\left[\right.$ and Hyeonae Jang ${ }^{2, *}$ \\ 1 Department of Natural Science, Korea Naval Academy, Changwon 51704, Korea; fieldsmin@gmail.com \\ 2 Department of Technology Management Engineering, Jeonju University, Jeonju 55069, Korea \\ * Correspondence: hajang@jj.ac.kr; Tel.: +82-63-220-2400
}

Citation: Min, S.; Jang, H. Case Study of Expected Loss Failure Mode and Effect Analysis Model Based on Maintenance Data. Appl. Sci. 2021, 11, 7349. https://doi.org/10.3390/ app11167349

Academic Editor: Tobias Meisen

Received: 31 May 2021

Accepted: 5 August 2021

Published: 10 August 2021

Publisher's Note: MDPI stays neutral with regard to jurisdictional claims in published maps and institutional affiliations.

Copyright: (c) 2021 by the authors. Licensee MDPI, Basel, Switzerland. This article is an open access article distributed under the terms and conditions of the Creative Commons Attribution (CC BY) license (https:// creativecommons.org/licenses/by/ $4.0 /)$.

\begin{abstract}
Failure mode and effect analysis (FMEA) is one of the most widely employed pre-evaluation techniques to avoid risks during the product design and manufacturing phases. Risk priority number (RPN), a risk assessment indicator used in FMEA, is widely used in the field due to its simple calculation process, but its limitations as an absolute risk assessment indicator have been pointed out. There has also been criticism of the unstructured nature and lack of systematicity in the FMEA procedures. This work proposes an expected loss-FMEA (EL-FMEA) model that organizes FMEA procedures and structures quantitative risk assessment metrics. In the EL-FMEA model, collectible maintenance record data is defined and based on this, the failure rate of components and systems and downtime and uptime of the system are calculated. Moreover, based on these calculated values, the expected economic loss is computed considering the failure detection time. It also provides an alternative coefficient to evaluate whether or not a detection system is installed to improve the expected loss of failure. Finally, a case study was conducted based on the maintenance record data, and the application procedure of the EL-FMEA model was presented in detail, and the practicality of this model was verified through the results.
\end{abstract}

Keywords: risk-evaluation; EL-FMEA; expected loss; alternative coefficient; maintenance record data

\section{Introduction}

FMEA is an efficient qualitative analysis method adopted in safety system engineering. The failure modes, failure effects, potential accidents, and the consequence of accidents can be systematically identified and evaluated by using the powerful tool [1]. The results of the FMEA can help analysts identify and correct the failure modes that have a detrimental effect on the system and improve its performance during the design and production stages [2]. Since its introduction as a methodology for preventing failures, FMEA has been broadly used in various industries, including the aerospace, automotive, semiconductor, aircraft, chemical plant, and steel industries [1,3-8].

Procedures for traditional FMEA are largely divided into system definition and FMEA worksheet creation. System definition identifies functions and operating modes as an introduction stage. The procedures required for FMEA worksheet creation are largely divided into failure mode analysis and risk assessment. Failure analysis has a way of enumerating failure modes for individual hardware or cataloging functional failures for products and components [9]. Next, the risk associated with a failure mode is usually evaluated using the risk priority number $(R P N)$, which corresponds to the mathematical product of the occurrence $(O)$, severity $(S)$, and detection $(D)$ of a failure-cause (i.e., $R P N=O \times S \times D)$. $R P N$ evaluation of a potential failure requires evaluating three risk factors, i.e., $O, S$ and $D$, via the 1-to-10 scale. The higher the RPN of a failure, the greater is the associated risk concerning system/product reliability [10].

However, this traditional FMEA risk-evaluation approach has often been extensively discussed in the existing literature for various reasons [2]. FMEA includes the following limitations in terms of worksheet creation procedures and RPN-based approaches. First, an 
$R P N$-based approach include (i) no consideration of relative importance among $O, S$, and $D$ [11-14]; (ii) difficulty to obtain the exact ratings on $O, S$, and $D$ because of the uncertainty and vagueness of FMEA group members' judgements [15-22]; (iii) no reflection of the interdependence between different causes of failure and their consequent effects [6,23-25]; and (iv) excessive reliance on expert intuition and experience instead of scientific methods for assessing three risk factors [26,27]. Next, the limitations in terms of FMEA procedures include: (i) FMEA is an inductive and non-structured approach to identify failure modes [28]; (ii) FMEA worksheets are only practical when there are a variety of experts and team members who are knowledgeable about the system [28]; (iii) identification of failure modes, causes, and effects requires a lot of time and effort by experts.

Many researchers have attempted to overcome the drawbacks mentioned above, thereby improving the FMEA risk-evaluation method in the process. Summarizing many studies that focused on improving the risk assessment method, Liu et al. reported that the most popular FMEA approach correspond to the fuzzy rule-based system [29-32], followed by the grey theory [13,14], cost-based model [16-18,33], AHP/ANP [24,34,35] and linear programming. Others included an integration-based approach $[21,22,26,27]$ and probability-based methodology [19,36]. Apart from these approaches, in our previous study $[10,36]$, we proposed an economic expected loss model in consideration of the time between the occurrence of the cause of failure and the time it takes to be detected when targeting a step-tier system and a multi-tier system. The proposed model is a timedependent FMEA model, which has the advantage of being able to intuitively assess the size of risk, unlike RPN, which is a traditional FMEA risk assessment index, RPN. Besides, Kwon et al. [37] suggested the expected loss model, in which failure was dependent on time, and the system was periodically monitored to prevent failures during its mission period. The loss due to each failure mode was assumed to depend on the remaining mission period of the system.

Next, among some studies that have focused on improving the FMEA procedure, Peeters et al. proposed a systematic structure that can identify the relationship between failure modes by combining FTA and FMEA, but it has a limitation in that it consumes a lot of time. [28]. Ahn et al. proposed a procedural model for process FMEA based on process function and equipment model (PFEM) representing the mapping between process functions and related equipment. The process FMEA performance method using PFEM is a methodology that enables them to be found by systematically accessing failure modes, effects, and causes by using a combined voice of customer (VOC) and defect history [38]. Kondrateva et al. proposed an algorithm for assessing the risk of accidents at energy facilities, based on the FMEA, event tree analysis (ETA), and human reliability assessment (HRA) methods, will increase the level of monitoring effectiveness of repair work organization of electrical equipment and its technical condition [39]. In addition, some studies have applied FTA and ETA to FMEA to systematically identify failure modes, causes, and effects [40,41].

Various studies are being conducted in terms of risk assessment methods and procedures to improve traditional FMEA. However, few studies suggest results applicable to the industry considering both the FMEA procedure and the risk assessment method in several previous studies, including our previous studies. Moreover, most previous studies presented risk assessment methods or procedures on an academic level, making it difficult for industrial field workers to apply the proposed methodology. Furthermore, although many studies have improved the limitations of RPNs as the risk assessment indicators, few cases have been found to present readily applicable indicators while intuitively assessing risks at industrial sites.

This study proposes an expected loss-based FMEA (EL-FMEA) model to present both the FMEA procedure and risk assessment indicators. In the EL-FMEA model, maintenance record data that can be sufficiently collected in the industrial field is first defined. Furthermore, based on the maintenance record data, the calculation method of system downtime, uptime, and the failure rate is presented in detail. Then, the method of cal- 
culating the expected loss due to the cause failure is presented. Finally, an alternative coefficient calculation method is also presented to determine whether to install a cause failure detection system based on expected loss. The composition of this study is described in detail in Section 2, defining the maintenance record data necessary for risk assessment and calculating the expected loss and the best alternative decision coefficient. In Section 3, a case study is performed based on maintenance record data processed for the experiment. Section 4 discusses the results of the case study and proposes ways to use them.

\section{Research Methodology}

\subsection{Data Definition and Modeling Procedure}

This section explains in detail variables and calculation processes that can quantitatively perform risk evaluation based on the EL-FMEA model. The indicators used in the EL-FMEA model are expected loss due to failure and the best alternative decision coefficient. The alternative meaning here is installing a detection system (e.g., a sensor) to prevent the recurrence of a failure. The procedures for the EL-FMEA model are shown in Table 1. Prerequisite data for the EL-FMEA model is defined as shown in Part (a) of Table 1 to calculate various indicators for risk assessment. The prerequisite data is defined as a variable necessary for calculating the expected loss based on the maintenance record data that can be easily collected in the industrial field. Based on the prerequisite data, we present the process of formulating intermediate variables step by step, as shown in Part (b) of Table 1. Based on the variables in this part, the expected loss and coefficient of determination for the best alternative can be calculated as shown in Part (c) of Table 1.

Table 1. Procedure for the EL-FMEA model.

(a) Prerequisite data

\begin{tabular}{cl}
\hline Variable & \\
\hline$T$ & Total time \\
$\tau$ & Regular maintenance period \\
$\tau_{i, 1}$ & $i^{\text {th }}$ system failure time \\
$\tau_{i, 2}$ & Re-operating time of the $i^{\text {th }}$ system failure \\
$n_{C}$ & Number of parts to repair a cause failure \\
$n_{\text {peop }}$ & Number of repairing people at each system failure \\
$n_{\text {prod }}$ & Number of productions per unit time \\
$\pi_{C}$ & Price of a part required to be repaired at each cause failure \\
$\pi_{\text {peop }}$ & Laboring cost per unit person per unit time \\
$\pi_{\text {prod }}$ & Price of a unit product \\
$\pi_{\text {sens }}$ & Price of a detection sensor \\
$\lambda_{\text {sens }}{ }^{*}$ & Sensor failure rate \\
$*$ If $\lambda_{\text {sens }}=1 / M T B F_{\text {sens }}$ is unknown and $M T B F_{\text {sens }}$ is expected to be longer than $T$, it can be set $1 / T$ conservatively.
\end{tabular}


Table 1. Cont.

(b) Intermediate variables

\begin{tabular}{|c|c|c|}
\hline Variable & Description & Formulation \\
\hline$N$ & Number of regular maintenances & $N=\frac{T}{\tau}$ \\
\hline$N_{C}$ & Number of cause failures & observation value \\
\hline$N_{S}$ & Number of system failures & observation value \\
\hline$\tau_{D}$ & Average system downtime & $\tau_{D}=\frac{1}{N_{S}} \sum_{i=1}^{N_{S}}\left(\tau_{i, 2}-\tau_{i, 1}\right)$ \\
\hline$\tau_{U}$ & Average system uptime & $\tau_{U}=\frac{T}{N_{S}}-\tau_{D}$ \\
\hline$\lambda_{C}$ & Cause failure rate & $\lambda_{C}=-\frac{\ln \left(1-N_{C} / N\right)}{\tau} \cong \frac{N_{C}}{N \tau}$ \\
\hline$\lambda_{S}$ & System failure rate & $\lambda_{S}=-\frac{\ln \left(1-N_{S} / N\right)}{\tau} \cong \frac{N_{S} \tau}{N \tau}$ \\
\hline$\alpha$ & Maintenance cost of a cause failure & $\alpha=n_{C} \times \pi_{C}$ \\
\hline$\beta$ & Maintenance cost of a system failure & observation value \\
\hline$\theta$ & Loss per unit time due to system breakdown & $\theta=n_{\text {peop }} \pi_{\text {peop }}+n_{\text {prod }} \pi_{\text {prod }}$ \\
\hline
\end{tabular}

(c) Output values

\begin{tabular}{|c|c|c|}
\hline Variable & Description & Formulation \\
\hline$L$ & Expected loss for $k$-causes system & $\begin{array}{l}L=T \sum_{i=1}^{k}\left[\lambda_{C_{i}} \alpha_{i}+\lambda_{S_{i}}\left(\beta_{i}+\theta \tau_{D_{i}}\right)\right] \\
\text { [see Equation (4)] }\end{array}$ \\
\hline$L_{\text {sens }}$ & $\begin{array}{l}\text { Expected loss } k \text {-causes system with detection } \\
\text { sensors }\end{array}$ & $\begin{array}{l}L_{\text {sens }}=T \sum_{i=1}^{k}\left(\lambda_{C_{i}} \alpha_{i}+\lambda_{S_{i}} \alpha_{i}+\lambda_{\text {sens }_{i}} \pi_{\text {sensi }}\right) \\
\text { [see Equation (6)] } \\
m=\frac{L_{\text {sens }}}{L} \\
; \text { install detection sensor for } m<c_{1}, \\
\text { do not install detection sensor for } m>c_{2} \text {, } \\
\text { hold off otherwise. } \\
c_{1}=0.8 \text { and } c_{2}=1.2 \text {, for instance. }\end{array}$ \\
\hline
\end{tabular}

First of all, the primary data required for FMEA performance has failure modes, causes, and failure effects, which can be organized as shown in Table 2. Based on FMEA's primary data, the prerequisite data is organized as shown in Part (a) of Table 1.

Table 2. FMEA format of MIL-STD-1629 $\left.{ }^{*}\right)$.

\begin{tabular}{cccccc}
\hline $\begin{array}{c}\text { Failure Modes } \\
\text { and Causes }\end{array}$ & $\begin{array}{c}\text { Operational } \\
\text { Mode }\end{array}$ & $\begin{array}{c}\text { Failure } \\
\text { Effects }\end{array}$ & $\begin{array}{c}\text { Failure } \\
\text { Detection } \\
\text { Method }\end{array}$ & $\begin{array}{c}\text { Compensating } \\
\text { Provisions }\end{array}$ & Remarks \\
\hline- & - & - & - & - & -
\end{tabular}

* FMEA standards have evolved based on the MIL-STD-1629 specification established by the Pentagon, which focuses on minimizing the risk to internal and external customers by identifying the impact of failure based on most functional analysis [38].

The total time $(T)$ is calculated by multiplying the working days by $24 \mathrm{~h}$ a day as the system operating time. In the regular maintenance period $(\tau)$, it generally means an inspection cycle performed for preventive maintenance in the industrial field. System failure time $\left(\tau_{i, 1}\right)$ and re-operating time $\left(\tau_{i, 2}\right)$ of the system failure are defined for system down and uptime calculation. Moreover, the number of parts to repair a cause failure $\left(n_{C}\right)$, number of repairing people at each system failure $\left(n_{\text {peop }}\right)$, number of productions per unit time $\left(n_{\text {prod }}\right)$, price of parts required to be repaired at each cause failure $\left(\pi_{C}\right)$, laboring cost per unit person per unit time $\left(\pi_{\text {peop }}\right)$, price of a unit product $\left(\pi_{\text {prod }}\right)$, price of a detection sensor $\left(\pi_{\text {sens }}\right)$, sensor failure rate are defined $\left(\lambda_{\text {sens }}\right)$. Here, the price of the detection sensor means an installation price of a sensor for detecting a cause failure.

Second, based on the prerequisite data defined in Part (a) of Table 1, intermediate variables for the EL-FMEA model are calculated according to the procedure in Part (b) of 
Table 1. By performing the procedure in Part (b), as shown in Part (c) of Table 1, two types of expected loss and the alternative coefficient can be calculated. The detailed calculation procedure is described in the next Section 2.2.

\subsection{Risk Evaluation Modeling}

In this study, the probability of cause failure and system failure was assumed to be exponentially distributed with each failure rate. We calculated the expected value of loss for the cases in a system with detection sensors or does not have them. First, we considered a system of no detection sensor that the failure causes are checked only by a constant maintenance period. Changing or repairing faulted components is carried out to detect the abnormality of cause during regular maintenance. However, there are cases where a cause failure occurs and leads to system failure. In this case, changing or repairing faulted components is carried out instantly other than the maintenance period. Second, we considered a system of detection sensors. Then, regular maintenances are unnecessary. We assume that there is no system failure because alarms occur when the cause failure occurs, so preemptive response is possible.

We calculated the expected value of loss when there is no detection sensor. When the regular maintenance period increases, the cost of cause failure decreases, but system failure increases. We calculated the expected loss by regular and corrective maintenance. The criteria for determining whether to set up the detection sensor are presented by comparing the cost of the detection sensor with the expected loss.

In advance, we assume that the cause failures and system failures occur in random with exponential distribution. The causes are checked every maintenance cycle, and abnormal parts are exchanged or repaired to renew all causes after each maintenance. The probability that a cause failure occurred and was detected at the next maintenance period equals the cumulative probability of an exponential distribution during the regular maintenance cycle. This is empirically equivalent to the discovery of cause failures relative to the total number of tests. The summary of cause failures is as follows:

- Cause failure

$$
\begin{gathered}
P\{\text { cause failure occurs within time } \tau\}=1-e^{-\lambda_{C} \tau}=\frac{N_{C}}{N} \\
\qquad \lambda_{C}=-\frac{\ln \left(1-N_{C} / N\right)}{\tau^{2}} \\
M T B F_{C}=\frac{1}{\lambda_{C}} \cong \frac{N \tau}{N_{C}}=\frac{T}{N_{C}} \text { for } N_{C} \ll N
\end{gathered}
$$

Similarly, the probability that a system failure occurred and was detected in a system uptime is equal to the cumulative probability of an exponential distribution. This is empirically equivalent to the number of discovery of system failures relative to the total number of tests. The summary of system failures is as follows:

- System failure

$$
\begin{gathered}
P\{\text { system failure occurs within time } \tau\}=1-e^{-\lambda_{S} \tau}=\frac{N_{S}}{N} \\
\qquad \lambda_{S}=-\frac{\ln \left(1-N_{S} / N\right)}{\tau_{\tau}} \\
M T B F_{S}=\frac{1}{\lambda_{S}} \cong \frac{N \tau}{N_{S}}=\frac{T}{N_{S}} \text { for } N_{S} \ll N
\end{gathered}
$$

We calculated the case where the detection sensor is installed on the system and not on the system. First, the loss function of the case without the detection sensor is as follows.

- Expected loss without detection sensor of 1-cause system:

$$
\begin{aligned}
& L(\tau)=N_{C} \alpha+N_{S} \beta+N_{S} \theta \tau_{D} \\
& =\frac{T}{M T B F_{C}} \alpha+\frac{T}{M T B F_{S}} \beta+\frac{T}{M T B F_{S}} \theta \tau_{D} \\
& =T\left[\lambda_{C} \alpha+\lambda_{S}\left(\beta+\theta \tau_{D}\right)\right]
\end{aligned}
$$

- $\quad$ Expected loss without detection sensor of $k$-causes system: 


$$
\begin{aligned}
& L(\tau)=\sum_{i=1}^{k} N_{C_{i}} \alpha_{i}+\sum_{i=1}^{k} N_{S_{i}} \beta_{i}+\sum_{i=1}^{k} N_{S_{i}} \theta \tau_{D i} \\
& =\sum_{i=1}^{k}\left(\frac{T}{M T B F_{C_{i}}} \alpha_{i}+\frac{T}{M T B F_{S_{i}}} \beta_{i}+\frac{T}{M T B F_{S_{i}}} \theta \tau_{D_{i}}\right) \\
& =T \sum_{i=1}^{k}\left[\lambda_{C_{i}} \alpha_{i}+\lambda_{S_{i}}\left(\beta_{i}+\theta \tau_{D_{i}}\right)\right]
\end{aligned}
$$

Second, the loss function of the case with the detection sensor is as follows. System failure is reduced by cause failure, and a sensor is alerted from a cause failure before the system failure. Thus, it is reasonable to say that the sum of the numbers of the cause failures and system failures when the sensor is not installed is the number of cause failures when the sensor is mounted. Therefore:

- Detection sensor with 1-cause system: there does not occur a system failure

$$
\begin{aligned}
& L_{\text {sens }}=N_{C}^{\prime} \alpha+N_{\text {sens }} \pi_{\text {sens }} \\
& \quad ; N_{C}^{\prime} \text { is the number of cause failures with a sensor } \\
& =N_{C} \alpha+N_{S} \alpha+N_{\text {sens }} \pi_{\text {sens }} \\
& =\frac{T \alpha}{M T B F_{C}}+\frac{T \alpha}{M T B F_{S}}+\frac{T \pi_{\text {sens }}}{M T B F_{\text {sens }}} \\
& =T\left(\lambda_{C} \alpha+\lambda_{S} \alpha+\lambda_{\text {sens }} \pi_{\text {sens }}\right)
\end{aligned}
$$

- Detection sensor with $k$-causes system: there does not occur a system failure

$$
\begin{aligned}
& L_{\text {sens }}=\sum_{i=1}^{k}\left(N_{C_{i}}^{\prime} \alpha_{i}+N_{\text {sens }_{i}} \pi_{\text {sens }_{i}}\right) \\
& ; N_{C_{i}}^{\prime} \text { is the number of } i-\text { th cause failures with sensors } \\
& =\sum_{i=1}^{k}\left(N_{C_{i}} \alpha_{i}+N_{S_{i}} \alpha_{i}+N_{\text {sens }_{i}} \pi_{\text {sens }_{i}}\right) \\
& =\sum_{i=1}^{k}\left(\frac{T \alpha_{i}}{M T B F_{C_{i}}}+\frac{T \alpha_{i}}{M T B F_{S_{i}}}+\frac{T \pi_{\text {sens }_{i}}}{M T B F_{\text {sens }_{i}}}\right) \\
& =T \sum_{i=1}^{k}\left(\lambda_{C_{i}} \alpha_{i}+\lambda_{S_{i}} \alpha_{i}+\lambda_{\text {sens }_{i}} \pi_{\text {sens }_{i}}\right)
\end{aligned}
$$

If $L_{\text {sens }}$ is significantly lower than $L$, system administrators should consider mounting detection sensors for cost down due to the system failure.

\section{Case Study}

\subsection{Example Case}

This paper aims to perform a quantified risk assessment by presenting an analysis procedure (Table 1) for calculating the expected loss of a failure based on the maintenance record data obtained in the industrial field. As preliminary work for field application, realistic maintenance records were generated and analyzed based on the EL-FMEA model (see Appendix A). When generating maintenance records, the regular maintenance period was set to 15 days, and three types of maintenance types were considered as follows:

(i) Regular Maintenance (RM): If there is no detection sensor, replace or repair parts due to cause failure found during the regular maintenance period.

(ii) Corrective Maintenance (CM): In the absence of a detection sensor, irregular repairs cause failure to system failure.

(iii) Sensor Maintenance (SM): If there is a detection sensor, replacing or repairing parts due to the detected cause failure. Parts with sensors are excluded from the regular maintenance period.

The maintenance record data (Appendix A) we modeled are based on the assumption of general manufacturing facilities and consisted of 12 failure modes, 12 failure causes and eight items. Items 1 to 4 are equipped with sensors, so only SM is performed. On the other hand, items 5 to 8 are not equipped with sensors, so RM and CM are performed. Therefore, 
in this case study, based on the EL-FMEA model, Items 1 to 4 estimate the expected loss ( $\left.L_{\text {sens }}\right)$ when there is a detection sensor, and Items 5 to 8 estimate the expected loss $(L)$ when there is no detection sensor. Finally, in Items 5 to 8 , the expected loss ( $\left.L_{\text {sens }}\right)$ is first estimated before the sensor is installed to determine whether to install the detection sensor. The coefficient of determination for the best alternative $(m)$ is calculated.

\subsection{Results}

Based on the maintenance record in Appendix A, the intermediate variables in part $b$ in Table 1 were calculated as shown in Table 3. $\tau_{D}, \tau_{U}, \lambda_{C}$, and $\lambda_{S}$ were calculated for Item 5 to Item 8 without a detection sensor, and in the case of $\lambda_{\text {sens, }}$ it was calculated considering the case where a detection sensor was installed.

Table 3. Reliability parameter estimation from maintenance record data.

\begin{tabular}{cccccc}
\hline Item Variable & $\tau_{D}[h]$ & $\tau_{U}[h]$ & $\lambda_{C}\left[10^{-4} h^{-1}\right]$ & $\lambda_{S}\left[10^{-4} h^{-1}\right]$ & $\lambda_{\text {sens }}\left[10^{-5} h^{-1}\right]$ \\
\hline Item05 & 1.33 & 8286.67 & 3.218 & 1.207 & 2.011 \\
Item06 & 2.50 & $12,429.50$ & 2.413 & 0.804 & 2.011 \\
Item07 & 1.67 & $12,430.33$ & 2.815 & 0.804 & 2.011 \\
Item08 & 2.00 & $24,862.00$ & 1.609 & 0.402 & 2.011 \\
\hline
\end{tabular}

Based on the results in Table 3, the EL-FMEA results are summarized in Table 4. First, we calculated the expected loss when there are detection sensors from Item 1 to 4 . In the case of an item with a detection sensor, since it is detected before the system's failure, the loss due to the system's failure is not included, but the cost of the detection sensor is considered. Among the items with detection sensors, Item 1, which has the highest component price and the highest occurrence frequency, showed the highest expected loss.

Table 4. Results of the EL-FMEA simulation for case study.

\begin{tabular}{|c|c|c|c|c|c|c|c|c|c|c|c|c|}
\hline $\begin{array}{c}\text { Maintenance } \\
\text { Type }\end{array}$ & $\begin{array}{c}\text { No. of } \\
S M\end{array}$ & $\begin{array}{c}\text { No. of } \\
R M\end{array}$ & $\begin{array}{c}\text { No. of } \\
C M\end{array}$ & $\begin{array}{l}\text { Cause } \\
\text { Type }\end{array}$ & $\begin{array}{l}\text { Item } \\
\text { Type }\end{array}$ & $n_{C}$ & $\pi_{C}$ & $n_{\text {peop }}$ & $\pi_{\text {peop }}$ & $\pi_{\text {sens }}$ & $L$ & $L_{\text {sens }}$ \\
\hline \multirow{4}{*}{$\begin{array}{c}\text { Sensor } \\
\text { maintenance } \\
(S M)\end{array}$} & 12 & - & - & CA01 & Item01 & 1 & $\$ 75$ & - & - & $\$ 500$ & - & $\$ 1150$ \\
\hline & 4 & - & - & CA02 & Item02 & 2 & $\$ 30$ & - & - & $\$ 400$ & - & $\$ 440$ \\
\hline & 8 & - & - & CA03 & Item03 & 1 & $\$ 40$ & - & - & $\$ 450$ & - & $\$ 545$ \\
\hline & 5 & - & - & CA04 & Item04 & 1 & $\$ 20$ & - & - & $\$ 300$ & - & $\$ 250$ \\
\hline \multirow{4}{*}{$\begin{array}{c}\text { Regular } \\
\text { Maintenance } \\
\quad(R M)\end{array}$} & - & 8 & - & CA05 & Item05 & 1 & $\$ 15$ & - & - & - & $\$ 120$ & - \\
\hline & - & 6 & - & CA06 & Item06 & 1 & $\$ 18$ & - & - & - & $\$ 108$ & - \\
\hline & - & 7 & - & CA07 & Item07 & 2 & $\$ 10$ & - & - & - & $\$ 140$ & - \\
\hline & - & 4 & - & CA08 & Item08 & 3 & $\$ 3$ & - & - & - & $\$ 36$ & - \\
\hline \multirow{4}{*}{$\begin{array}{c}\text { Corrective } \\
\text { Maintenance } \\
\text { (CM) }\end{array}$} & - & - & 3 & CA09 & Item05 & 1 & $\$ 15$ & 1 & $\$ 20$ & - & $\$ 518$ & - \\
\hline & - & - & 2 & CA10 & Item06 & 1 & $\$ 18$ & 2 & $\$ 20$ & - & $\$ 442$ & - \\
\hline & - & - & 2 & CA11 & Item07 & 2 & $\$ 10$ & 2 & $\$ 20$ & - & $\$ 471$ & - \\
\hline & - & - & 1 & CA12 & Item08 & 3 & $\$ 3$ & 1 & $\$ 20$ & - & $\$ 134$ & - \\
\hline
\end{tabular}

Next, in the case of Item 5 to 8, both RM and CM were performed, and each failure cause is different. In the case of RM, it is found that the expected loss is lower than that of $\mathrm{CM}$, even for the same item, because it is found before system failure. In terms of items in Item 5,6 , and 7, the expected loss is relatively higher than that of Item 8 because it causes system failure and requires frequent repairs during the regular maintenance period. Also, in item 1 to item 3, the expected loss was high despite the presence of a detection sensor in terms of the entire item. In this case, it will be necessary to consider adjusting the sensor's sensitivity or replacing it with highly reliable parts to lower expected losses.

Finally, the coefficient of determination for the best alternative $(m)$ was derived based on the expected loss from items 5 to 8 without a detection sensor. First, the total expected loss from items 5 to 8 is summarized in Table 5 . For example, the expected loss for Item 5 is $\$ 638$, which is the sum of the RM cost (\$120) and the CM cost (\$518). When a detection 
sensor is installed to lower the expected loss $(L)$, the $L_{\text {sens }}$ was calculated and based on this, $m$ was derived. $m$ can establish a criterion from the user's perspective, for example, here, when $m$ is less than 0.8 , it is assumed that a detection sensor is installed. Therefore, in the case of Item 5 to $7, m$ is less than 0.7 , so a detection sensor is to be installed. On the other hand, in the case of Item 8 , it is withheld.

Table 5. Expected loss after installation of detection sensor: Expected loss calculation when the detection sensors are installed on Item 5 to 8 .

\begin{tabular}{|c|c|c|c|c|c|c|c|}
\hline State & $\begin{array}{l}\text { Maintenance } \\
\text { Type }\end{array}$ & $\begin{array}{l}\text { Item } \\
\text { Type }\end{array}$ & $\pi_{\text {sens }}$ & $L$ & $L_{\text {sens }}$ & $m$ & $\begin{array}{c}\text { Sensor } \\
\text { Installation }\end{array}$ \\
\hline \multirow{4}{*}{ As is } & \multirow{4}{*}{$\begin{array}{c}\text { Regular } \\
\text { and } \\
\text { Corrective } \\
\text { Maintenance }\end{array}$} & Item05 & - & $\$ 638$ & - & - & - \\
\hline & & Item06 & - & $\$ 550$ & - & - & - \\
\hline & & Item07 & - & $\$ 611$ & - & - & - \\
\hline & & Item08 & - & $\$ 170$ & - & - & - \\
\hline \multirow{4}{*}{ To be } & \multirow{4}{*}{$\begin{array}{c}\text { Sensor } \\
\text { Maintenance }\end{array}$} & Item05 & $\$ 500$ & - & $\$ 415$ & 0.650 & Yes \\
\hline & & Item06 & $\$ 400$ & - & $\$ 344$ & 0.626 & Yes \\
\hline & & Item07 & $\$ 450$ & - & $\$ 405$ & 0.663 & Yes \\
\hline & & Item08 & $\$ 300$ & - & $\$ 195$ & 1.147 & Withhold \\
\hline
\end{tabular}

\section{Discussion}

The conventional FMEA model classes the risk of cause failure as occurrence $(O)$, severity $(S)$, and detection $(D)$, quantities them with 1-10 point scales, and then derivatives a risk priority number $(R P N)$ with multiplying them. $R P N$ is used as a rank of risk among several causes, but it does not mean the amount of the risk. However, LOSS calculated in our EL-FMEA model means the actual cost that the system operator is most interested in. Therefore, the operator can check the magnitude of the risk and the priority of risk of a cause from the LOSS. In our model, occurrence $(O)$ corresponds to the probability of a cause failure, detection $(D)$ to the probability of a cause detection, and severity $(S)$ to the cost of the cause.

We created dummy data that can be collected on-site to verify the model's usefulness (See Tables A1 and A2). The system we envision consists of Item 01 to 08 . Item 01 to 04 are equipped with sensors, so only the sensor maintenance (SM) occurs. However, items 05 to 08 are not equipped with sensors, so regular maintenance (RM) and corrective maintenance (CM) occur simultaneously. From the maintenance table, we could derive the cause failure rates of Item 05 to 08 and the system failure rates, uptime, and downtime caused by Item 05 to 08 . From the detection and failure rate of the already secured items 05 to 08 , we derived alternative coefficients to determine whether the sensor is installed in items 05 to 08. In our example, the alternative coefficients of items 05 to 07 are smaller than 0.8 , and the coefficient of Item 08 is 1.147 . Therefore, it is considered economical to install sensors on items 05 to 07 and not in Item 08.

Collecting maintenance record data in the industrial fields has recently become very convenient due to various innovative technologies. The EL-FMEA model is applicable to the risk management of systems and processes in manufacturing and service industries. First, in the manufacturing industry, maintenance records are generally collected for quality control, but it is often not guaranteed whether indicators such as failure rate and expected loss (probability) can be calculated based on the collected data. Therefore, a data collection method and procedure that can be quantitatively analyzed in this study are presented through the EL-FMEA model. Even in the service industry, it is known that service failures, customer complaints, and complaint handling time are collected to manage the service process. Similarly, if the EL-FMEA model is applied, it will be possible to calculate the service failure rate, expected loss, and alternative decision coefficient.

We believe that applying the EL-FMEA model to the industrial field has the following advantages: (i) The EL-FMEA model is also fully applicable as a commonly used data processing tool (e.g., MS-Excel). (ii) The risk due to failure can be intuitively evaluated 
through the expected loss (economic aspect). That is, an acceptable cost of loss can be set to suit the situation; (iii) The expected profit can be calculated before the risk of failure is eliminated. In other words, a decision can be made based on the difference or ratio between the existing expected loss and the expected loss after the detection sensor is installed (iv) If the data defined to perform the EL-FMEA is continuously collected, the failure rate and operation rate of the system and items can be obtained, and the reliability of the system and items can also be calculated; (v) If the system of the EL-FMEA model is established in the company system, it can be used to verify the quality improvement goal and achievement. In other words, it will be possible to establish failure rate and expected loss reduction goals and check whether the goals are achieved.

If the EL-FMEA model is continuously used in the industrial field, we think that probability-based multifaceted analysis can be performed. In the future, based on this study, we will propose an optimal maintenance period that minimizes the expected loss but try to present it in a way that can be easily applied in the industrial field. In addition, in the Republic of Korea, various punishments are applied when a human accident occurs in the industrial field, according to the Occupational Safety and Health Act. Recently, through an interview with field workers, we gathered that a risk assessment considering the size of such a loss is necessary. In the future, we intend to present a more advanced EL-FMEA model along with measures that can realistically reflect such a situation.

Author Contributions: Conceptualization, H.J. and S.M.; methodology, H.J. and S.M.; modeling, S.M.; validation, H.J. and S.M.; writing—original draft preparation, H.J. and S.M.; writing-review and editing, H.J. and SM.; funding acquisition, H.J. Both authors have read and agreed to the published version of the manuscript.

Funding: This research was supported by the Research Grant of Jeonju University in 2020. This work was supported by the National Research Foundation of Korea (NRF) in a grant funded by the Korean government (MSIT) (No. 2019R1G1A1010335).

Conflicts of Interest: The authors declare no conflict of interest.

\section{Appendix A}

Based on the prerequisite data defined in Section 2.1 of this study, we arbitrarily modeled the case study's maintenance record data (Section 3) as Table A2. We modeled the maintenance record data based on a general facility consisting of 12 failure modes, 12 failure causes, and eight items. Three types of maintenance were considered: (i) Regular maintenance (RM); (ii) corrective maintenance (CM); and (iii) sensor maintenance (SM). Items 1 to 4 are equipped with sensors, so only sensor maintenance (SM) occurs. On the other hand, items 5 to 8 are not equipped with sensors, so regular maintenance (RM) and corrective maintenance $(\mathrm{CM})$ occur. Abbreviations and variables used in Table A2 are summarized in Table A1.

Table A1. Abbreviations and variables.

\begin{tabular}{|c|c|}
\hline Division & Contents \\
\hline Abbreviations & $\begin{array}{l}\text { Maintenance type(MT); Regular maintenance(RM); Corrective } \\
\text { Maintenance(CM); Sensor Maintenance(SM); Date(DT); System maintenance } \\
\text { start time(MS); System maintenance end time(ME); Maintenance range(MR); } \\
\text { System failure(SF); System replacement(SR); Failure mode(FM); Cause } \\
\text { failure(CF); Parts maintenance type(PT): Parts for maintenance (PM), } \\
\text { Replacement(RT); Repair(RR); }\end{array}$ \\
\hline Variables & $\begin{array}{l}i^{\text {th }} \text { system failure time }\left(\tau_{i, 1}\right) \text {; Re-operating time of the } i^{t h} \text { system failure }\left(\tau_{i, 2}\right) ; \\
\text { Maintenance cost of a system failure }(\beta) \text {; Number of parts to repair a cause } \\
\text { failure }\left(n_{C}\right) \text {; Price of parts required to be repaired at each cause failure }\left(\pi_{C}\right) \text {; } \\
\text { Number of productions per unit time }\left(n_{\text {prod }}\right) \text {; Price of a unit product }\left(\pi_{\text {prod }}\right) \text {; } \\
\text { Number of repairing people at each system failure }\left(n_{\text {peop }}\right) \text {; Laboring cost per } \\
\text { unit person per unit time }\left(\pi_{\text {peop }}\right) ; \text { Economic loss }(\text { EL }) ;\end{array}$ \\
\hline
\end{tabular}


Table A2. Maintenance record data for the EL-FMEA for case study.

\begin{tabular}{|c|c|c|c|c|c|c|c|c|c|c|c|c|c|c|c|c|c|c|c|c|}
\hline MT & $D T$ & MS & $M E$ & $M R$ & $S F$ & $S R$ & $F M$ & $C F$ & $P T$ & $P M$ & $\tau_{i, 1}$ & $\tau_{i, 2}$ & $\beta$ & $n_{C}$ & $\pi_{C}$ & $n_{\text {prod }}$ & $\pi_{\text {prod }}$ & $n_{\text {peop }}$ & $\pi_{\text {peop }}$ & $E L$ \\
\hline RM01 & 1 March 2020 & 08:00 & 09:00 & whole & $\mathrm{N}$ & $\mathrm{N}$ & $\mathrm{N} / \mathrm{A}$ & $\mathrm{N} / \mathrm{A}$ & $\mathrm{N} / \mathrm{A}$ & $\mathrm{N} / \mathrm{A}$ & $\mathrm{N} / \mathrm{A}$ & $\mathrm{N} / \mathrm{A}$ & $\mathrm{N} / \mathrm{A}$ & $\mathrm{N} / \mathrm{A}$ & $\mathrm{N} / \mathrm{A}$ & 200 & $\$ 2.0$ & $\mathrm{~N} / \mathrm{A}$ & $\mathrm{N} / \mathrm{A}$ & - \\
\hline RM02 & 16 March 2020 & 08:00 & 09:00 & whole & $\mathrm{N}$ & $\mathrm{N}$ & $\mathrm{N} / \mathrm{A}$ & $\mathrm{N} / \mathrm{A}$ & $\mathrm{N} / \mathrm{A}$ & $\mathrm{N} / \mathrm{A}$ & $\mathrm{N} / \mathrm{A}$ & $\mathrm{N} / \mathrm{A}$ & $\mathrm{N} / \mathrm{A}$ & $\mathrm{N} / \mathrm{A}$ & $\mathrm{N} / \mathrm{A}$ & 200 & $\$ 2.0$ & $\mathrm{~N} / \mathrm{A}$ & $\mathrm{N} / \mathrm{A}$ & - \\
\hline SM01 & 21 March 2020 & $\mathrm{~N} / \mathrm{A}$ & $\mathrm{N} / \mathrm{A}$ & $\mathrm{N} / \mathrm{A}$ & $\mathrm{N}$ & $\mathrm{N}$ & FM10 & CA10 & RT & Item10 & $\mathrm{N} / \mathrm{A}$ & $\mathrm{N} / \mathrm{A}$ & $\mathrm{N} / \mathrm{A}$ & 2 & $\$ 30$ & 200 & $\$ 2.0$ & 2 & $\$ 20$ & $\$ 60$ \\
\hline RM03 & 31 March 2020 & 08:00 & 09:00 & whole & $\mathrm{N}$ & $\mathrm{N}$ & $\mathrm{N} / \mathrm{A}$ & $\mathrm{N} / \mathrm{A}$ & $\mathrm{N} / \mathrm{A}$ & $\mathrm{N} / \mathrm{A}$ & $\mathrm{N} / \mathrm{A}$ & $\mathrm{N} / \mathrm{A}$ & $\mathrm{N} / \mathrm{A}$ & $\mathrm{N} / \mathrm{A}$ & $\mathrm{N} / \mathrm{A}$ & 200 & $\$ 2.0$ & $\mathrm{~N} / \mathrm{A}$ & $\mathrm{N} / \mathrm{A}$ & - \\
\hline RM04 & 15 April 2020 & 08:00 & 09:00 & whole & $\mathrm{N}$ & $\mathrm{N}$ & $\mathrm{N} / \mathrm{A}$ & $\mathrm{N} / \mathrm{A}$ & $\mathrm{N} / \mathrm{A}$ & $\mathrm{N} / \mathrm{A}$ & $\mathrm{N} / \mathrm{A}$ & $\mathrm{N} / \mathrm{A}$ & $\mathrm{N} / \mathrm{A}$ & $\mathrm{N} / \mathrm{A}$ & $\mathrm{N} / \mathrm{A}$ & 200 & $\$ 2.0$ & $\mathrm{~N} / \mathrm{A}$ & $\mathrm{N} / \mathrm{A}$ & - \\
\hline SM02 & 23 April 2020 & $\mathrm{~N} / \mathrm{A}$ & $\mathrm{N} / \mathrm{A}$ & $\mathrm{N} / \mathrm{A}$ & $\mathrm{N}$ & $\mathrm{N}$ & FM09 & CA09 & RT & Item09 & $\mathrm{N} / \mathrm{A}$ & $\mathrm{N} / \mathrm{A}$ & $\mathrm{N} / \mathrm{A}$ & 1 & $\$ 75$ & 200 & $\$ 2.0$ & 2 & $\$ 20$ & $\$ 75$ \\
\hline RM05 & 30 April 2020 & 08:00 & 09:00 & whole & $\mathrm{N}$ & $\mathrm{N}$ & $\mathrm{N} / \mathrm{A}$ & $\mathrm{N} / \mathrm{A}$ & $\mathrm{N} / \mathrm{A}$ & N/A & $\mathrm{N} / \mathrm{A}$ & $\mathrm{N} / \mathrm{A}$ & $\mathrm{N} / \mathrm{A}$ & $\mathrm{N} / \mathrm{A}$ & $\mathrm{N} / \mathrm{A}$ & 200 & $\$ 2.0$ & $\mathrm{~N} / \mathrm{A}$ & $\mathrm{N} / \mathrm{A}$ & - \\
\hline RM07 & 30 May 2020 & 08:00 & 09:00 & whole & $\mathrm{N}$ & $\mathrm{N}$ & FM01 & CA01 & $\mathrm{RR}$ & Item01 & $\mathrm{N} / \mathrm{A}$ & $\mathrm{N} / \mathrm{A}$ & $\mathrm{N} / \mathrm{A}$ & 1 & $\$ 15$ & 200 & $\$ 2.0$ & 1 & $\$ 20$ & $\$ 15$ \\
\hline SM03 & 7 June 2020 & $\mathrm{~N} / \mathrm{A}$ & $\mathrm{N} / \mathrm{A}$ & $\mathrm{N} / \mathrm{A}$ & $\mathrm{N}$ & $\mathrm{N}$ & FM11 & CA11 & RT & Item11 & $\mathrm{N} / \mathrm{A}$ & $\mathrm{N} / \mathrm{A}$ & $\mathrm{N} / \mathrm{A}$ & 1 & $\$ 40$ & 200 & $\$ 2.0$ & 1 & $\$ 20$ & $\$ 40$ \\
\hline RM08 & 14 June 2020 & 08:00 & 09:00 & whole & $\mathrm{N}$ & $\mathrm{N}$ & $\mathrm{N} / \mathrm{A}$ & $\mathrm{N} / \mathrm{A}$ & $\mathrm{N} / \mathrm{A}$ & $\mathrm{N} / \mathrm{A}$ & $\mathrm{N} / \mathrm{A}$ & $\mathrm{N} / \mathrm{A}$ & $\mathrm{N} / \mathrm{A}$ & $\mathrm{N} / \mathrm{A}$ & $\mathrm{N} / \mathrm{A}$ & 200 & $\$ 2.0$ & $\mathrm{~N} / \mathrm{A}$ & $\mathrm{N} / \mathrm{A}$ & - \\
\hline RM09 & 29 June 2020 & 08:00 & 09:00 & whole & $\mathrm{N}$ & $\mathrm{N}$ & $\mathrm{N} / \mathrm{A}$ & $\mathrm{N} / \mathrm{A}$ & $\mathrm{N} / \mathrm{A}$ & $\mathrm{N} / \mathrm{A}$ & $\mathrm{N} / \mathrm{A}$ & $\mathrm{N} / \mathrm{A}$ & $\mathrm{N} / \mathrm{A}$ & $\mathrm{N} / \mathrm{A}$ & $\mathrm{N} / \mathrm{A}$ & 200 & $\$ 2.0$ & $\mathrm{~N} / \mathrm{A}$ & $\mathrm{N} / \mathrm{A}$ & - \\
\hline CM02 & 4 July 2020 & $\mathrm{~N} / \mathrm{A}$ & $\mathrm{N} / \mathrm{A}$ & $\mathrm{N} / \mathrm{A}$ & $\mathrm{Y}$ & $\mathrm{N}$ & FM06 & CA06 & RR & Item06 & $12: 00$ & $13: 30$ & $\$ 25$ & 1 & $\$ 50$ & 200 & $\$ 2.0$ & 1 & $\$ 20$ & $\$ 311$ \\
\hline SM04 & 8 July 2020 & $\mathrm{~N} / \mathrm{A}$ & $\mathrm{N} / \mathrm{A}$ & $\mathrm{N} / \mathrm{A}$ & $\mathrm{N}$ & $\mathrm{N}$ & FM12 & CA12 & RT & Item12 & $\mathrm{N} / \mathrm{A}$ & $\mathrm{N} / \mathrm{A}$ & $\mathrm{N} / \mathrm{A}$ & 1 & $\$ 20$ & 200 & $\$ 2.0$ & 1 & $\$ 20$ & $\$ 20$ \\
\hline RM10 & 14 July 2020 & 08:00 & 09:00 & whole & $\mathrm{N}$ & $\mathrm{N}$ & $\mathrm{N} / \mathrm{A}$ & $\mathrm{N} / \mathrm{A}$ & $\mathrm{N} / \mathrm{A}$ & N/A & $\mathrm{N} / \mathrm{A}$ & $\mathrm{N} / \mathrm{A}$ & $\mathrm{N} / \mathrm{A}$ & $\mathrm{N} / \mathrm{A}$ & $\mathrm{N} / \mathrm{A}$ & 200 & $\$ 2.0$ & $\mathrm{~N} / \mathrm{A}$ & $\mathrm{N} / \mathrm{A}$ & - \\
\hline SM05 & 25 July 2020 & $\mathrm{~N} / \mathrm{A}$ & $\mathrm{N} / \mathrm{A}$ & $\mathrm{N} / \mathrm{A}$ & $\mathrm{N}$ & $\mathrm{N}$ & FM10 & CA10 & RT & Item10 & $\mathrm{N} / \mathrm{A}$ & $\mathrm{N} / \mathrm{A}$ & $\mathrm{N} / \mathrm{A}$ & 2 & $\$ 30$ & 200 & $\$ 2.0$ & 2 & $\$ 20$ & $\$ 60$ \\
\hline RM11 & 29 July 2020 & 08:00 & 09:00 & whole & $\mathrm{N}$ & $\mathrm{N}$ & $\mathrm{N} / \mathrm{A}$ & $\mathrm{N} / \mathrm{A}$ & $\mathrm{N} / \mathrm{A}$ & $\mathrm{N} / \mathrm{A}$ & $\mathrm{N} / \mathrm{A}$ & $\mathrm{N} / \mathrm{A}$ & $\mathrm{N} / \mathrm{A}$ & $\mathrm{N} / \mathrm{A}$ & $\mathrm{N} / \mathrm{A}$ & 200 & $\$ 2.0$ & $\mathrm{~N} / \mathrm{A}$ & $\mathrm{N} / \mathrm{A}$ & - \\
\hline RM13 & 28 August 2020 & 08:00 & 09:00 & whole & $\mathrm{N}$ & $\mathrm{N}$ & $\mathrm{N} / \mathrm{A}$ & $\mathrm{N} / \mathrm{A}$ & $\mathrm{N} / \mathrm{A}$ & $\mathrm{N} / \mathrm{A}$ & $\mathrm{N} / \mathrm{A}$ & $\mathrm{N} / \mathrm{A}$ & $\mathrm{N} / \mathrm{A}$ & $\mathrm{N} / \mathrm{A}$ & $\mathrm{N} / \mathrm{A}$ & 200 & $\$ 2.0$ & $\mathrm{~N} / \mathrm{A}$ & $\mathrm{N} / \mathrm{A}$ & - \\
\hline RM14 & 12 September 2020 & 08:00 & 09:00 & whole & $\mathrm{N}$ & $\mathrm{N}$ & $\mathrm{N} / \mathrm{A}$ & $\mathrm{N} / \mathrm{A}$ & $\mathrm{N} / \mathrm{A}$ & $\mathrm{N} / \mathrm{A}$ & $\mathrm{N} / \mathrm{A}$ & $\mathrm{N} / \mathrm{A}$ & $\mathrm{N} / \mathrm{A}$ & $\mathrm{N} / \mathrm{A}$ & $\mathrm{N} / \mathrm{A}$ & 200 & $\$ 2.0$ & $\mathrm{~N} / \mathrm{A}$ & $\mathrm{N} / \mathrm{A}$ & - \\
\hline RM15 & 27 September 2020 & 08:00 & 09:00 & whole & $\mathrm{N}$ & $\mathrm{N}$ & $\mathrm{N} / \mathrm{A}$ & $\mathrm{N} / \mathrm{A}$ & $\mathrm{N} / \mathrm{A}$ & $\mathrm{N} / \mathrm{A}$ & $\mathrm{N} / \mathrm{A}$ & $\mathrm{N} / \mathrm{A}$ & $\mathrm{N} / \mathrm{A}$ & $\mathrm{N} / \mathrm{A}$ & $\mathrm{N} / \mathrm{A}$ & 200 & $\$ 2.0$ & $\mathrm{~N} / \mathrm{A}$ & $\mathrm{N} / \mathrm{A}$ & - \\
\hline SM06 & 30 September 2020 & $\mathrm{~N} / \mathrm{A}$ & $\mathrm{N} / \mathrm{A}$ & $\mathrm{N} / \mathrm{A}$ & $\mathrm{N}$ & $\mathrm{N}$ & FM09 & CA09 & RT & Item09 & $\mathrm{N} / \mathrm{A}$ & $\mathrm{N} / \mathrm{A}$ & $\mathrm{N} / \mathrm{A}$ & 1 & $\$ 75$ & 200 & $\$ 2.0$ & 2 & $\$ 20$ & $\$ 75$ \\
\hline RM16 & 12 October 2020 & 08:00 & 09:00 & whole & $\mathrm{N}$ & $\mathrm{N}$ & $\mathrm{N} / \mathrm{A}$ & $\mathrm{N} / \mathrm{A}$ & $\mathrm{N} / \mathrm{A}$ & $\mathrm{N} / \mathrm{A}$ & $\mathrm{N} / \mathrm{A}$ & $\mathrm{N} / \mathrm{A}$ & $\mathrm{N} / \mathrm{A}$ & $\mathrm{N} / \mathrm{A}$ & $\mathrm{N} / \mathrm{A}$ & 200 & $\$ 2.0$ & $\mathrm{~N} / \mathrm{A}$ & $\mathrm{N} / \mathrm{A}$ & - \\
\hline CM03 & 18 October 2020 & $\mathrm{~N} / \mathrm{A}$ & $\mathrm{N} / \mathrm{A}$ & $\mathrm{N} / \mathrm{A}$ & $\mathrm{Y}$ & $\mathrm{N}$ & FM05 & CA05 & $\mathrm{RR}$ & Item05 & $11: 00$ & $11: 40$ & $\$ 45$ & 3 & $\$ 10$ & 200 & $\$ 2.0$ & 2 & $\$ 20$ & $\$ 87$ \\
\hline SM07 & 20 October 2020 & $\mathrm{~N} / \mathrm{A}$ & $\mathrm{N} / \mathrm{A}$ & $\mathrm{N} / \mathrm{A}$ & $\mathrm{N}$ & $\mathrm{N}$ & FM10 & CA10 & RT & Item10 & $\mathrm{N} / \mathrm{A}$ & $\mathrm{N} / \mathrm{A}$ & $\mathrm{N} / \mathrm{A}$ & 2 & $\$ 30$ & 200 & $\$ 2.0$ & 2 & $\$ 20$ & $\$ 60$ \\
\hline RM17 & 27 October 2020 & 08:00 & 09:00 & whole & $\mathrm{N}$ & $\mathrm{N}$ & FM01 & CA01 & RR & Item01 & $\mathrm{N} / \mathrm{A}$ & $\mathrm{N} / \mathrm{A}$ & $\mathrm{N} / \mathrm{A}$ & 1 & $\$ 15$ & 200 & $\$ 2.0$ & 1 & $\$ 20$ & $\$ 15$ \\
\hline RM18 & 11 November 2020 & 08:00 & 09:00 & whole & $\mathrm{N}$ & $\mathrm{N}$ & $\mathrm{N} / \mathrm{A}$ & $\mathrm{N} / \mathrm{A}$ & $\mathrm{N} / \mathrm{A}$ & $\mathrm{N} / \mathrm{A}$ & $\mathrm{N} / \mathrm{A}$ & $\mathrm{N} / \mathrm{A}$ & $\mathrm{N} / \mathrm{A}$ & $\mathrm{N} / \mathrm{A}$ & $\mathrm{N} / \mathrm{A}$ & 200 & $\$ 2.0$ & $\mathrm{~N} / \mathrm{A}$ & $\mathrm{N} / \mathrm{A}$ & - \\
\hline SM08 & 21 November 2020 & $\mathrm{~N} / \mathrm{A}$ & $\mathrm{N} / \mathrm{A}$ & $\mathrm{N} / \mathrm{A}$ & $\mathrm{N}$ & $\mathrm{N}$ & FM11 & CA11 & RT & Item11 & $\mathrm{N} / \mathrm{A}$ & $\mathrm{N} / \mathrm{A}$ & $\mathrm{N} / \mathrm{A}$ & 1 & $\$ 40$ & 200 & $\$ 2.0$ & 1 & $\$ 20$ & $\$ 40$ \\
\hline RM19 & 26 November 2020 & 08:00 & 09:00 & whole & $\mathrm{N}$ & $\mathrm{N}$ & $\mathrm{N} / \mathrm{A}$ & $\mathrm{N} / \mathrm{A}$ & $\mathrm{N} / \mathrm{A}$ & $\mathrm{N} / \mathrm{A}$ & $\mathrm{N} / \mathrm{A}$ & $\mathrm{N} / \mathrm{A}$ & $\mathrm{N} / \mathrm{A}$ & $\mathrm{N} / \mathrm{A}$ & $\mathrm{N} / \mathrm{A}$ & 200 & $\$ 2.0$ & $\mathrm{~N} / \mathrm{A}$ & $\mathrm{N} / \mathrm{A}$ & - \\
\hline RM20 & 11 December 2020 & $08: 00$ & 09:00 & whole & $\mathrm{N}$ & $\mathrm{N}$ & FM03 & CA03 & RR & Item03 & $\mathrm{N} / \mathrm{A}$ & $\mathrm{N} / \mathrm{A}$ & $\mathrm{N} / \mathrm{A}$ & 2 & $\$ 10$ & 200 & $\$ 2.0$ & 1 & $\$ 20$ & $\$ 20$ \\
\hline SM09 & 17 December 2020 & $\mathrm{~N} / \mathrm{A}$ & $\mathrm{N} / \mathrm{A}$ & $\mathrm{N} / \mathrm{A}$ & $\mathrm{N}$ & $\mathrm{N}$ & FM12 & CA12 & RT & Item 12 & $\mathrm{~N} / \mathrm{A}$ & $\mathrm{N} / \mathrm{A}$ & $\mathrm{N} / \mathrm{A}$ & 1 & $\$ 20$ & 200 & $\$ 2.0$ & 1 & $\$ 20$ & $\$ 20$ \\
\hline RM21 & 26 December 2020 & 08:00 & 09:00 & whole & $\mathrm{N}$ & $\mathrm{N}$ & $\mathrm{N} / \mathrm{A}$ & $\mathrm{N} / \mathrm{A}$ & $\mathrm{N} / \mathrm{A}$ & $\mathrm{N} / \mathrm{A}$ & $\mathrm{N} / \mathrm{A}$ & $\mathrm{N} / \mathrm{A}$ & $\mathrm{N} / \mathrm{A}$ & $\mathrm{N} / \mathrm{A}$ & $\mathrm{N} / \mathrm{A}$ & 200 & $\$ 2.0$ & $\mathrm{~N} / \mathrm{A}$ & $\mathrm{N} / \mathrm{A}$ & - \\
\hline RM22 & 10 January 2021 & 08:00 & 09:00 & whole & $\mathrm{N}$ & $\mathrm{N}$ & $\mathrm{N} / \mathrm{A}$ & $\mathrm{N} / \mathrm{A}$ & $\mathrm{N} / \mathrm{A}$ & $\mathrm{N} / \mathrm{A}$ & $\mathrm{N} / \mathrm{A}$ & $\mathrm{N} / \mathrm{A}$ & $\mathrm{N} / \mathrm{A}$ & $\mathrm{N} / \mathrm{A}$ & $\mathrm{N} / \mathrm{A}$ & 200 & $\$ 2.0$ & $\mathrm{~N} / \mathrm{A}$ & $\mathrm{N} / \mathrm{A}$ & - \\
\hline RM23 & 25 January 2021 & 08:00 & 09:00 & whole & $\mathrm{N}$ & $\mathrm{N}$ & $\mathrm{N} / \mathrm{A}$ & $\mathrm{N} / \mathrm{A}$ & $\mathrm{N} / \mathrm{A}$ & N/A & $\mathrm{N} / \mathrm{A}$ & $\mathrm{N} / \mathrm{A}$ & $\mathrm{N} / \mathrm{A}$ & $\mathrm{N} / \mathrm{A}$ & $\mathrm{N} / \mathrm{A}$ & 200 & $\$ 2.0$ & $\mathrm{~N} / \mathrm{A}$ & $\mathrm{N} / \mathrm{A}$ & - \\
\hline SM10 & 1 February 2021 & $\mathrm{~N} / \mathrm{A}$ & $\mathrm{N} / \mathrm{A}$ & $\mathrm{N} / \mathrm{A}$ & $\mathrm{N}$ & $\mathrm{N}$ & FM09 & CA09 & RT & Item09 & $\mathrm{N} / \mathrm{A}$ & $\mathrm{N} / \mathrm{A}$ & $\mathrm{N} / \mathrm{A}$ & 1 & $\$ 75$ & 200 & $\$ 2.0$ & 2 & $\$ 20$ & $\$ 75$ \\
\hline RM24 & 9 February 2021 & 08:00 & 09:00 & whole & $\mathrm{N}$ & $\mathrm{N}$ & $\mathrm{N} / \mathrm{A}$ & $\mathrm{N} / \mathrm{A}$ & $\mathrm{N} / \mathrm{A}$ & $\mathrm{N} / \mathrm{A}$ & $\mathrm{N} / \mathrm{A}$ & $\mathrm{N} / \mathrm{A}$ & $\mathrm{N} / \mathrm{A}$ & $\mathrm{N} / \mathrm{A}$ & $\mathrm{N} / \mathrm{A}$ & 200 & $\$ 2.0$ & $\mathrm{~N} / \mathrm{A}$ & $\mathrm{N} / \mathrm{A}$ & - \\
\hline
\end{tabular}


Table 2. Cont.

\begin{tabular}{|c|c|c|c|c|c|c|c|c|c|c|c|c|c|c|c|c|c|c|c|c|}
\hline$M T$ & $D T$ & MS & $M E$ & $M R$ & $S F$ & $S R$ & $F M$ & $C F$ & $P T$ & $P M$ & $\tau_{i, 1}$ & $\tau_{i, 2}$ & $\beta$ & $n_{C}$ & $\pi_{C}$ & $n_{\text {prod }}$ & $\pi_{\text {prod }}$ & $n_{\text {peop }}$ & $\pi_{\text {peop }}$ & $E L$ \\
\hline RM25 & 24 February 2021 & 08:00 & 09:00 & whole & $\mathrm{N}$ & $\mathrm{N}$ & $\mathrm{N} / \mathrm{A}$ & $\mathrm{N} / \mathrm{A}$ & $\mathrm{N} / \mathrm{A}$ & $\mathrm{N} / \mathrm{A}$ & $\mathrm{N} / \mathrm{A}$ & $\mathrm{N} / \mathrm{A}$ & $\mathrm{N} / \mathrm{A}$ & $\mathrm{N} / \mathrm{A}$ & $\mathrm{N} / \mathrm{A}$ & 200 & $\$ 2.0$ & $\mathrm{~N} / \mathrm{A}$ & $\mathrm{N} / \mathrm{A}$ & - \\
\hline SM11 & 10 March 2021 & $\mathrm{~N} / \mathrm{A}$ & $\mathrm{N} / \mathrm{A}$ & $\mathrm{N} / \mathrm{A}$ & $\mathrm{N}$ & $\mathrm{N}$ & FM12 & CA12 & RT & Item12 & $\mathrm{N} / \mathrm{A}$ & $\mathrm{N} / \mathrm{A}$ & $\mathrm{N} / \mathrm{A}$ & 1 & $\$ 20$ & 200 & $\$ 2.0$ & 1 & $\$ 20$ & $\$ 20$ \\
\hline RM26 & 11 March 2021 & 08:00 & 09:00 & whole & $\mathrm{N}$ & $\mathrm{N}$ & $\mathrm{N} / \mathrm{A}$ & $\mathrm{N} / \mathrm{A}$ & $\mathrm{N} / \mathrm{A}$ & $\mathrm{N} / \mathrm{A}$ & $\mathrm{N} / \mathrm{A}$ & $\mathrm{N} / \mathrm{A}$ & $\mathrm{N} / \mathrm{A}$ & $\mathrm{N} / \mathrm{A}$ & $\mathrm{N} / \mathrm{A}$ & 200 & $\$ 2.0$ & $\mathrm{~N} / \mathrm{A}$ & $\mathrm{N} / \mathrm{A}$ & - \\
\hline SM12 & 9 April 2021 & $\mathrm{~N} / \mathrm{A}$ & $\mathrm{N} / \mathrm{A}$ & $\mathrm{N} / \mathrm{A}$ & $\mathrm{N}$ & $\mathrm{N}$ & FM11 & CA11 & RT & Item11 & $\mathrm{N} / \mathrm{A}$ & $\mathrm{N} / \mathrm{A}$ & $\mathrm{N} / \mathrm{A}$ & 1 & $\$ 40$ & 200 & $\$ 2.0$ & 1 & $\$ 20$ & $\$ 40$ \\
\hline RM28 & 10 April 2021 & 08:00 & 09:00 & whole & $\mathrm{N}$ & $\mathrm{N}$ & $\mathrm{N} / \mathrm{A}$ & $\mathrm{N} / \mathrm{A}$ & $\mathrm{N} / \mathrm{A}$ & $\mathrm{N} / \mathrm{A}$ & $\mathrm{N} / \mathrm{A}$ & $\mathrm{N} / \mathrm{A}$ & $\mathrm{N} / \mathrm{A}$ & $\mathrm{N} / \mathrm{A}$ & $\mathrm{N} / \mathrm{A}$ & 200 & $\$ 2.0$ & $\mathrm{~N} / \mathrm{A}$ & $\mathrm{N} / \mathrm{A}$ & - \\
\hline RM29 & 25 April 2021 & 08:00 & 09:00 & whole & $\mathrm{N}$ & $\mathrm{N}$ & $\mathrm{N} / \mathrm{A}$ & $\mathrm{N} / \mathrm{A}$ & $\mathrm{N} / \mathrm{A}$ & $\mathrm{N} / \mathrm{A}$ & $\mathrm{N} / \mathrm{A}$ & $\mathrm{N} / \mathrm{A}$ & $\mathrm{N} / \mathrm{A}$ & $\mathrm{N} / \mathrm{A}$ & $\mathrm{N} / \mathrm{A}$ & 200 & $\$ 2.0$ & $\mathrm{~N} / \mathrm{A}$ & $\mathrm{N} / \mathrm{A}$ & - \\
\hline RM30 & 10 May 2021 & 08:00 & 09:00 & whole & $\mathrm{N}$ & $\mathrm{N}$ & $\mathrm{N} / \mathrm{A}$ & $\mathrm{N} / \mathrm{A}$ & $\mathrm{N} / \mathrm{A}$ & N/A & $\mathrm{N} / \mathrm{A}$ & $\mathrm{N} / \mathrm{A}$ & $\mathrm{N} / \mathrm{A}$ & $\mathrm{N} / \mathrm{A}$ & $\mathrm{N} / \mathrm{A}$ & 200 & $\$ 2.0$ & $\mathrm{~N} / \mathrm{A}$ & $\mathrm{N} / \mathrm{A}$ & - \\
\hline RM31 & 25 May 2021 & 08:00 & 09:00 & whole & $\mathrm{N}$ & $\mathrm{N}$ & $\mathrm{N} / \mathrm{A}$ & $\mathrm{N} / \mathrm{A}$ & $\mathrm{N} / \mathrm{A}$ & $\mathrm{N} / \mathrm{A}$ & $\mathrm{N} / \mathrm{A}$ & $\mathrm{N} / \mathrm{A}$ & $\mathrm{N} / \mathrm{A}$ & $\mathrm{N} / \mathrm{A}$ & $\mathrm{N} / \mathrm{A}$ & 200 & $\$ 2.0$ & $\mathrm{~N} / \mathrm{A}$ & $\mathrm{N} / \mathrm{A}$ & - \\
\hline CM04 & 29 May 2021 & $\mathrm{~N} / \mathrm{A}$ & $\mathrm{N} / \mathrm{A}$ & $\mathrm{N} / \mathrm{A}$ & $\mathrm{Y}$ & $\mathrm{N}$ & FM05 & CA05 & $\mathrm{RR}$ & Item05 & $9: 40$ & $10: 00$ & $\$ 45$ & 3 & $\$ 10$ & 200 & $\$ 2.0$ & 2 & $\$ 20$ & $\$ 81$ \\
\hline RM32 & 9 June 2021 & 08:00 & 09:00 & whole & $\mathrm{N}$ & $\mathrm{N}$ & $\mathrm{N} / \mathrm{A}$ & $\mathrm{N} / \mathrm{A}$ & $\mathrm{N} / \mathrm{A}$ & $\mathrm{N} / \mathrm{A}$ & $\mathrm{N} / \mathrm{A}$ & $\mathrm{N} / \mathrm{A}$ & $\mathrm{N} / \mathrm{A}$ & $\mathrm{N} / \mathrm{A}$ & $\mathrm{N} / \mathrm{A}$ & 200 & $\$ 2.0$ & $\mathrm{~N} / \mathrm{A}$ & $\mathrm{N} / \mathrm{A}$ & - \\
\hline SM14 & 15 June 2021 & $\mathrm{~N} / \mathrm{A}$ & $\mathrm{N} / \mathrm{A}$ & $\mathrm{N} / \mathrm{A}$ & $\mathrm{N}$ & $\mathrm{N}$ & FM11 & CA11 & RT & Item11 & $\mathrm{N} / \mathrm{A}$ & $\mathrm{N} / \mathrm{A}$ & $\mathrm{N} / \mathrm{A}$ & 1 & $\$ 40$ & 200 & $\$ 2.0$ & 1 & $\$ 20$ & $\$ 40$ \\
\hline RM33 & 24 June 2021 & 08:00 & 09:00 & whole & $\mathrm{N}$ & $\mathrm{N}$ & FM04 & CA04 & RR & Item04 & $\mathrm{N} / \mathrm{A}$ & $\mathrm{N} / \mathrm{A}$ & $\mathrm{N} / \mathrm{A}$ & 1 & $\$ 3$ & 200 & $\$ 2.0$ & 1 & $\$ 20$ & $\$ 3$ \\
\hline CM05 & 30 June 2021 & $\mathrm{~N} / \mathrm{A}$ & $\mathrm{N} / \mathrm{A}$ & $\mathrm{N} / \mathrm{A}$ & $\mathrm{Y}$ & $\mathrm{N}$ & FM07 & CA07 & RR & Item07 & 9:00 & 10:00 & $\$ 20$ & 1 & $\$ 5$ & 200 & $\$ 2.0$ & 1 & $\$ 20$ & $\$ 42$ \\
\hline RM34 & 9 July 2021 & 08:00 & 09:00 & whole & $\mathrm{N}$ & $\mathrm{N}$ & $\mathrm{N} / \mathrm{A}$ & $\mathrm{N} / \mathrm{A}$ & $\mathrm{N} / \mathrm{A}$ & $\mathrm{N} / \mathrm{A}$ & $\mathrm{N} / \mathrm{A}$ & $\mathrm{N} / \mathrm{A}$ & $\mathrm{N} / \mathrm{A}$ & $\mathrm{N} / \mathrm{A}$ & $\mathrm{N} / \mathrm{A}$ & 200 & $\$ 2.0$ & $\mathrm{~N} / \mathrm{A}$ & $\mathrm{N} / \mathrm{A}$ & - \\
\hline RM35 & 24 July 2021 & 08:00 & 09:00 & whole & $\mathrm{N}$ & $\mathrm{N}$ & $\mathrm{N} / \mathrm{A}$ & $\mathrm{N} / \mathrm{A}$ & $\mathrm{N} / \mathrm{A}$ & $\mathrm{N} / \mathrm{A}$ & $\mathrm{N} / \mathrm{A}$ & $\mathrm{N} / \mathrm{A}$ & $\mathrm{N} / \mathrm{A}$ & $\mathrm{N} / \mathrm{A}$ & $\mathrm{N} / \mathrm{A}$ & 200 & $\$ 2.0$ & $\mathrm{~N} / \mathrm{A}$ & $\mathrm{N} / \mathrm{A}$ & - \\
\hline SM15 & 31 July 2021 & $\mathrm{~N} / \mathrm{A}$ & $\mathrm{N} / \mathrm{A}$ & $\mathrm{N} / \mathrm{A}$ & $\mathrm{N}$ & $\mathrm{N}$ & FM09 & CA09 & RT & Item09 & $\mathrm{N} / \mathrm{A}$ & $\mathrm{N} / \mathrm{A}$ & $\mathrm{N} / \mathrm{A}$ & 1 & $\$ 75$ & 200 & $\$ 2.0$ & 2 & $\$ 20$ & $\$ 75$ \\
\hline RM37 & 23 August 2021 & $08: 00$ & 09:00 & whole & $\mathrm{N}$ & $\mathrm{N}$ & $\mathrm{N} / \mathrm{A}$ & $\mathrm{N} / \mathrm{A}$ & $\mathrm{N} / \mathrm{A}$ & $\mathrm{N} / \mathrm{A}$ & $\mathrm{N} / \mathrm{A}$ & $\mathrm{N} / \mathrm{A}$ & $\mathrm{N} / \mathrm{A}$ & $\mathrm{N} / \mathrm{A}$ & $\mathrm{N} / \mathrm{A}$ & 200 & $\$ 2.0$ & $\mathrm{~N} / \mathrm{A}$ & $\mathrm{N} / \mathrm{A}$ & - \\
\hline RM38 & 7 September 2021 & $08: 00$ & 09:00 & whole & $\mathrm{N}$ & $\mathrm{N}$ & $\mathrm{N} / \mathrm{A}$ & $\mathrm{N} / \mathrm{A}$ & $\mathrm{N} / \mathrm{A}$ & $\mathrm{N} / \mathrm{A}$ & $\mathrm{N} / \mathrm{A}$ & $\mathrm{N} / \mathrm{A}$ & $\mathrm{N} / \mathrm{A}$ & $\mathrm{N} / \mathrm{A}$ & $\mathrm{N} / \mathrm{A}$ & 200 & $\$ 2.0$ & $\mathrm{~N} / \mathrm{A}$ & $\mathrm{N} / \mathrm{A}$ & - \\
\hline SM16 & 18 September 2021 & $\mathrm{~N} / \mathrm{A}$ & $\mathrm{N} / \mathrm{A}$ & $\mathrm{N} / \mathrm{A}$ & $\mathrm{N}$ & $\mathrm{N}$ & FM11 & CA11 & RT & Item11 & $\mathrm{N} / \mathrm{A}$ & $\mathrm{N} / \mathrm{A}$ & $\mathrm{N} / \mathrm{A}$ & 1 & $\$ 40$ & 200 & $\$ 2.0$ & 1 & $\$ 20$ & $\$ 40$ \\
\hline RM39 & 22 September 2021 & 08:00 & 09:00 & whole & $\mathrm{N}$ & $\mathrm{N}$ & $\mathrm{N} / \mathrm{A}$ & $\mathrm{N} / \mathrm{A}$ & $\mathrm{N} / \mathrm{A}$ & $\mathrm{N} / \mathrm{A}$ & $\mathrm{N} / \mathrm{A}$ & $\mathrm{N} / \mathrm{A}$ & $\mathrm{N} / \mathrm{A}$ & $\mathrm{N} / \mathrm{A}$ & $\mathrm{N} / \mathrm{A}$ & 200 & $\$ 2.0$ & $\mathrm{~N} / \mathrm{A}$ & $\mathrm{N} / \mathrm{A}$ & - \\
\hline SM17 & 25 September 2021 & $\mathrm{~N} / \mathrm{A}$ & $\mathrm{N} / \mathrm{A}$ & $\mathrm{N} / \mathrm{A}$ & $\mathrm{N}$ & $\mathrm{N}$ & FM09 & CA09 & RT & Item09 & $\mathrm{N} / \mathrm{A}$ & $\mathrm{N} / \mathrm{A}$ & $\mathrm{N} / \mathrm{A}$ & 1 & $\$ 75$ & 200 & $\$ 2.0$ & 2 & $\$ 20$ & $\$ 75$ \\
\hline RM40 & 7 October 2021 & 08:00 & 09:00 & whole & $\mathrm{N}$ & $\mathrm{N}$ & FM02 & CA02 & RR & Item02 & $\mathrm{N} / \mathrm{A}$ & $\mathrm{N} / \mathrm{A}$ & $\mathrm{N} / \mathrm{A}$ & 1 & $\$ 18$ & 200 & $\$ 2.0$ & 2 & $\$ 20$ & $\$ 18$ \\
\hline RM41 & 22 October 2021 & 08:00 & 09:00 & whole & $\mathrm{N}$ & $\mathrm{N}$ & $\mathrm{N} / \mathrm{A}$ & $\mathrm{N} / \mathrm{A}$ & $\mathrm{N} / \mathrm{A}$ & $\mathrm{N} / \mathrm{A}$ & $\mathrm{N} / \mathrm{A}$ & $\mathrm{N} / \mathrm{A}$ & $\mathrm{N} / \mathrm{A}$ & $\mathrm{N} / \mathrm{A}$ & $\mathrm{N} / \mathrm{A}$ & 200 & $\$ 2.0$ & $\mathrm{~N} / \mathrm{A}$ & $\mathrm{N} / \mathrm{A}$ & - \\
\hline CM06 & 25 October 2021 & $\mathrm{~N} / \mathrm{A}$ & $\mathrm{N} / \mathrm{A}$ & $\mathrm{N} / \mathrm{A}$ & $\mathrm{Y}$ & $\mathrm{N}$ & FM08 & CA08 & RR & Item08 & $12: 00$ & $13: 30$ & $\$ 480$ & 2 & $\$ 95$ & 200 & $\$ 2.0$ & 2 & $\$ 20$ & $\$ 918$ \\
\hline SM18 & 29 October 2021 & $\mathrm{~N} / \mathrm{A}$ & $\mathrm{N} / \mathrm{A}$ & $\mathrm{N} / \mathrm{A}$ & $\mathrm{N}$ & $\mathrm{N}$ & FM09 & CA09 & RT & Item09 & $\mathrm{N} / \mathrm{A}$ & $\mathrm{N} / \mathrm{A}$ & $\mathrm{N} / \mathrm{A}$ & 1 & $\$ 75$ & 200 & $\$ 2.0$ & 2 & $\$ 20$ & $\$ 75$ \\
\hline RM42 & 6 November 2021 & 08:00 & 09:00 & whole & $\mathrm{N}$ & $\mathrm{N}$ & $\mathrm{N} / \mathrm{A}$ & $\mathrm{N} / \mathrm{A}$ & $\mathrm{N} / \mathrm{A}$ & $\mathrm{N} / \mathrm{A}$ & $\mathrm{N} / \mathrm{A}$ & $\mathrm{N} / \mathrm{A}$ & $\mathrm{N} / \mathrm{A}$ & $\mathrm{N} / \mathrm{A}$ & $\mathrm{N} / \mathrm{A}$ & 200 & $\$ 2.0$ & $\mathrm{~N} / \mathrm{A}$ & $\mathrm{N} / \mathrm{A}$ & - \\
\hline RM43 & 21 November 2021 & 08:00 & 09:00 & whole & $\mathrm{N}$ & $\mathrm{N}$ & $\mathrm{N} / \mathrm{A}$ & $\mathrm{N} / \mathrm{A}$ & $\mathrm{N} / \mathrm{A}$ & $\mathrm{N} / \mathrm{A}$ & $\mathrm{N} / \mathrm{A}$ & $\mathrm{N} / \mathrm{A}$ & $\mathrm{N} / \mathrm{A}$ & $\mathrm{N} / \mathrm{A}$ & $\mathrm{N} / \mathrm{A}$ & 200 & $\$ 2.0$ & $\mathrm{~N} / \mathrm{A}$ & $\mathrm{N} / \mathrm{A}$ & - \\
\hline RM44 & 6 December 2021 & 08:00 & 09:00 & whole & $\mathrm{N}$ & $\mathrm{N}$ & $\mathrm{N} / \mathrm{A}$ & $\mathrm{N} / \mathrm{A}$ & $\mathrm{N} / \mathrm{A}$ & $\mathrm{N} / \mathrm{A}$ & $\mathrm{N} / \mathrm{A}$ & $\mathrm{N} / \mathrm{A}$ & $\mathrm{N} / \mathrm{A}$ & $\mathrm{N} / \mathrm{A}$ & $\mathrm{N} / \mathrm{A}$ & 200 & $\$ 2.0$ & $\mathrm{~N} / \mathrm{A}$ & $\mathrm{N} / \mathrm{A}$ & - \\
\hline RM45 & 21 December 2021 & 08:00 & 09:00 & whole & $\mathrm{N}$ & $\mathrm{N}$ & $\mathrm{N} / \mathrm{A}$ & $\mathrm{N} / \mathrm{A}$ & $\mathrm{N} / \mathrm{A}$ & $\mathrm{N} / \mathrm{A}$ & $\mathrm{N} / \mathrm{A}$ & $\mathrm{N} / \mathrm{A}$ & $\mathrm{N} / \mathrm{A}$ & $\mathrm{N} / \mathrm{A}$ & $\mathrm{N} / \mathrm{A}$ & 200 & $\$ 2.0$ & $\mathrm{~N} / \mathrm{A}$ & $\mathrm{N} / \mathrm{A}$ & - \\
\hline RM46 & 5 January 2022 & 08:00 & 09:00 & whole & $\mathrm{N}$ & $\mathrm{N}$ & $\mathrm{N} / \mathrm{A}$ & $\mathrm{N} / \mathrm{A}$ & $\mathrm{N} / \mathrm{A}$ & $\mathrm{N} / \mathrm{A}$ & $\mathrm{N} / \mathrm{A}$ & $\mathrm{N} / \mathrm{A}$ & $\mathrm{N} / \mathrm{A}$ & $\mathrm{N} / \mathrm{A}$ & $\mathrm{N} / \mathrm{A}$ & 200 & $\$ 2.0$ & $\mathrm{~N} / \mathrm{A}$ & $\mathrm{N} / \mathrm{A}$ & - \\
\hline SM19 & 9 January 2022 & $\mathrm{~N} / \mathrm{A}$ & $\mathrm{N} / \mathrm{A}$ & $\mathrm{N} / \mathrm{A}$ & $\mathrm{N}$ & $\mathrm{N}$ & FM09 & CA09 & RT & Item09 & $\mathrm{N} / \mathrm{A}$ & $\mathrm{N} / \mathrm{A}$ & $\mathrm{N} / \mathrm{A}$ & 1 & $\$ 75$ & 200 & $\$ 2.0$ & 2 & $\$ 20$ & $\$ 75$ \\
\hline RM47 & 20 January 2022 & 08:00 & 09:00 & whole & $\mathrm{N}$ & $\mathrm{N}$ & $\mathrm{N} / \mathrm{A}$ & $\mathrm{N} / \mathrm{A}$ & $\mathrm{N} / \mathrm{A}$ & $\mathrm{N} / \mathrm{A}$ & $\mathrm{N} / \mathrm{A}$ & $\mathrm{N} / \mathrm{A}$ & $\mathrm{N} / \mathrm{A}$ & $\mathrm{N} / \mathrm{A}$ & $\mathrm{N} / \mathrm{A}$ & 200 & $\$ 2.0$ & $\mathrm{~N} / \mathrm{A}$ & $\mathrm{N} / \mathrm{A}$ & - \\
\hline RM48 & 4 February 2022 & $08: 00$ & 09:00 & whole & $\mathrm{N}$ & $\mathrm{N}$ & $\mathrm{N} / \mathrm{A}$ & $\mathrm{N} / \mathrm{A}$ & $\mathrm{N} / \mathrm{A}$ & $\mathrm{N} / \mathrm{A}$ & $\mathrm{N} / \mathrm{A}$ & $\mathrm{N} / \mathrm{A}$ & $\mathrm{N} / \mathrm{A}$ & $\mathrm{N} / \mathrm{A}$ & $\mathrm{N} / \mathrm{A}$ & 200 & $\$ 2.0$ & $\mathrm{~N} / \mathrm{A}$ & $\mathrm{N} / \mathrm{A}$ & - \\
\hline SM20 & 9 February 2022 & $\mathrm{~N} / \mathrm{A}$ & $\mathrm{N} / \mathrm{A}$ & $\mathrm{N} / \mathrm{A}$ & $\mathrm{N}$ & $\mathrm{N}$ & FM11 & CA11 & RT & Item 11 & $\mathrm{~N} / \mathrm{A}$ & $\mathrm{N} / \mathrm{A}$ & $\mathrm{N} / \mathrm{A}$ & 1 & $\$ 40$ & 200 & $\$ 2.0$ & 1 & $\$ 20$ & $\$ 40$ \\
\hline
\end{tabular}


Table A2. Cont.

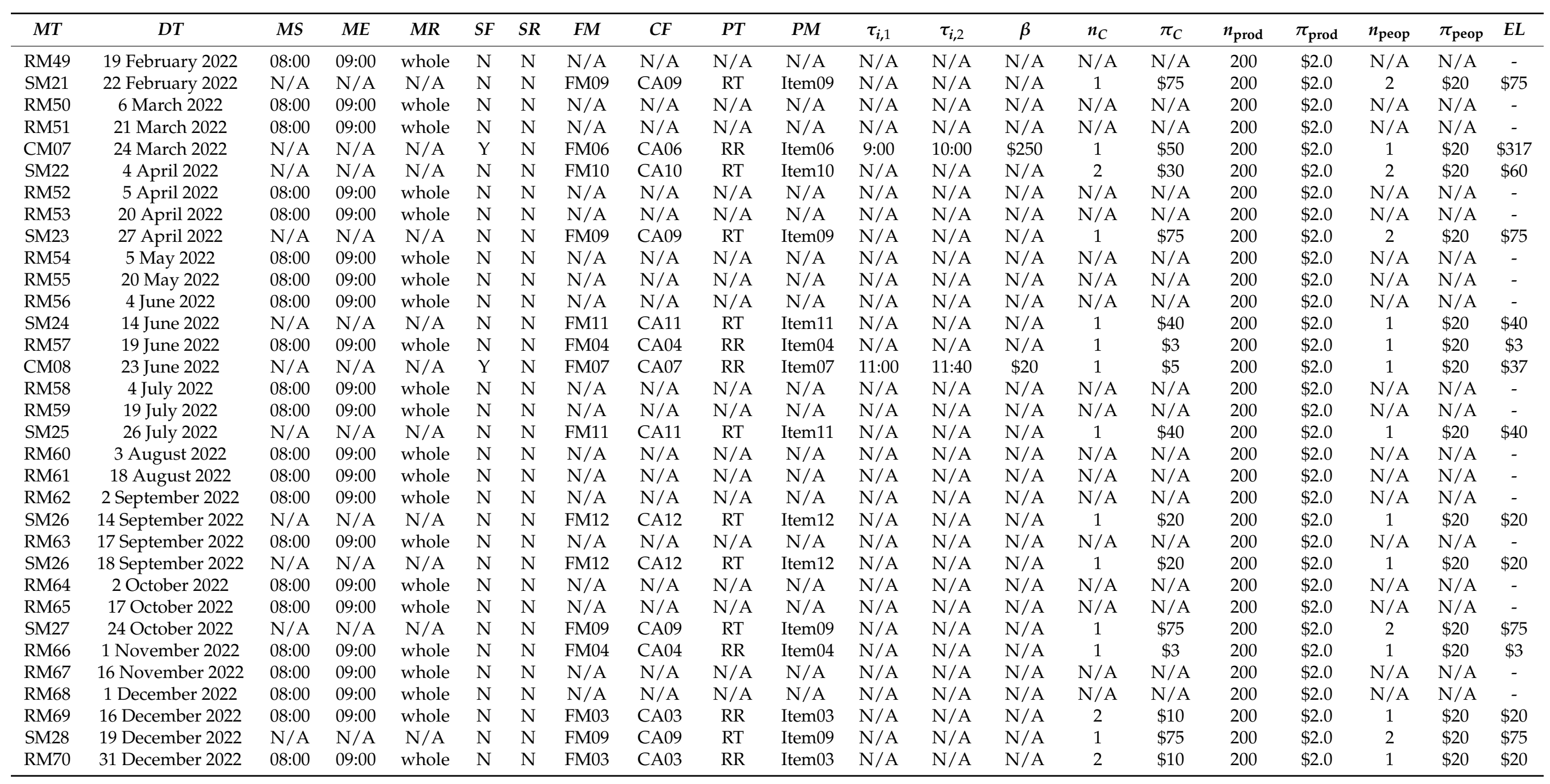




\section{References}

1. Wang, L.; Yan, F.; Wang, F.; Li, Z. FMEA-CM based quantitative risk assessment for process industries-A case study of coal-to-methanol plant in China. Process Saf. Environ. Prot. 2021, 149, 299-311. [CrossRef]

2. Liu, H.; Liu, L.; Liu, N. Risk evaluation approaches in failure mode and effects analysis: A literature review. Expert Syst. Appl. 2013, 40, 828-838. [CrossRef]

3. Geum, Y.; Cho, Y.; Park, Y. A systematic approach for diagnosing service failure: Service-specific FMEA and grey relational analysis approach. Math. Comput. Model. 2011, 54, 3126-3142. [CrossRef]

4. Santhosh, D.; Vinodh, S. Application of FMEA to an automotive leaf spring manufacturing organization. TQM J. 2012, 24, 260-274.

5. Yazdi, M.; Daneshvar, S.; Setareh, H. An extension to Fuzzy Developed Failure Mode and Effects Analysis (FDFMEA) application for aircraft landing system. Saf. Sci. 2017, 98, 113-123. [CrossRef]

6. Wang, W.; Liu, X.; Qin, Y.; Fu, Y. A risk evaluation and prioritization method for FMEA with prospect theory and Choquet integral. Saf. Sci. 2018, 110, 152-163. [CrossRef]

7. Deulgaonkar, V.R.; Ingolikar, N.; Borkar, A.; Ghute, S.; Awate, N. Failure analysis of diesel engine piston in transport utility vehicles. Eng. Fail. Anal. 2021, 120. [CrossRef]

8. Bhattacharjee, P.; Dey, V.; Mandal, U.K. Risk assessment by failure mode and effects analysis (FMEA) using an interval number based logistic regression model. Saf. Sci. 2020, 132, 104967. [CrossRef]

9. Yoo, J.M.; Ahn, D.G.; Jang, J.S. Review of FMEA. J. Appl. Reliab. 2019, 19, 318-333. [CrossRef]

10. Jang, H.; Min, S. Time-Dependent Probabilistic Approach of Failure Mode and Effect Analysis. Appl. Sci. 2019, 9, 4939. [CrossRef]

11. Fattahi, R.; Khalilzadeh, M. Risk evaluation using a novel hybrid method based on FMEA, extended MULTIMOORA, and AHP methods under fuzzy environment. Saf. Sci. 2018, 102, 290-300. [CrossRef]

12. Mentes, A.; Ozen, E. A hybrid risk analysis method for a yacht fuel system safety. Saf. Sci. 2015, 79, 94-104. [CrossRef]

13. Zhou, Q.; Thai, V.V. Fuzzy and grey theories in failure mode and effect analysis for tanker equipment failure prediction. Saf. Sci. 2016, 83, 74-79. [CrossRef]

14. Maniram Kumar, A.; Rajakarunakaran, S.; Pitchipoo, P.; Vimalesan, R. Fuzzy based risk prioritisation in an auto LPG dispensing station. Saf. Sci. 2018, 101, 231-247. [CrossRef]

15. Wang, Z.; Ran, Y.; Chen, Y.; Yu, H.; Zhang, G. Failure mode and effects analysis using extended matter-element model and AHP. Comput. Ind. Eng. 2020, 140, 106233. [CrossRef]

16. Rhee, S.J.; Ishii, K. Using cost based FMEA to enhance reliability and serviceability. Adv. Eng. Inform. 2003, 17, 179-188. [CrossRef]

17. Dong, C. Failure mode and effects analysis based on fuzzy utility cost estimation. Int. J. Qual. Reliab. Mgmt. 2007, 24, 958-971. [CrossRef]

18. von Ahsen, A. Cost-oriented failure mode and effects analysis. Int. J. Qual. Reliab. Mgmt. 2008, 25, 466-476. [CrossRef]

19. Parracho Sant'Anna, A. Probabilistic priority numbers for failure modes and effects analysis. Int. J. Qual. Reliab. Mgmt. 2012, 29, 349-362. [CrossRef]

20. Certa, A.; Hopps, F.; Inghilleri, R.; La Fata, C.M. A Dempster-Shafer Theory-based approach to the Failure Mode, Effects and Criticality Analysis (FMECA) under epistemic uncertainty: Application to the propulsion system of a fishing vessel. Reliab. Eng. Syst. Saf. 2017, 159, 69-79. [CrossRef]

21. Huang, J.; Li, Z.; Liu, H. New approach for failure mode and effect analysis using linguistic distribution assessments and TODIM method. Reliab. Eng. Syst. Saf. 2017, 167, 302-309. [CrossRef]

22. Catelani, M.; Ciani, L.; Venzi, M. Failure modes, mechanisms and effect analysis on temperature redundant sensor stage. Reliab. Eng. Syst. Saf. 2018, 180, 425-433. [CrossRef]

23. Kim, K.O.; Zuo, M.J. General model for the risk priority number in failure mode and effects analysis. Reliab. Eng. Syst. Saf. 2018, 169, 321-329. [CrossRef]

24. Ding, X.; Su, Q.; You, J.; Liu, H. Improving risk evaluation in FMEA with a hybrid multiple criteria decision making method. Int. J. Qual. Reliab. Mgmt. 2015, 32, 763-782.

25. Mohsen, O.; Fereshteh, N. An extended VIKOR method based on entropy measure for the failure modes risk assessment-A case study of the geothermal power plant (GPP). Saf. Sci. 2017, 92, 160-172. [CrossRef]

26. Lo, H.; Liou, J.J.H.; Huang, C.; Chuang, Y. A novel failure mode and effect analysis model for machine tool risk analysis. Reliab. Eng. Syst. Saf. 2019, 183, 173-183. [CrossRef]

27. Yousefi, S.; Alizadeh, A.; Hayati, J.; Baghery, M. HSE risk prioritization using robust DEA-FMEA approach with undesirable outputs: A study of automotive parts industry in Iran. Saf. Sci. 2018, 102, 144-158. [CrossRef]

28. Peeters, J.F.W.; Basten, R.J.I.; Tinga, T. Improving failure analysis efficiency by combining FTA and FMEA in a recursive manner. Reliab. Eng. Syst. Saf. 2018, 172, 36-44. [CrossRef]

29. Gul, M.; Yucesan, M.; Celik, E. A manufacturing failure mode and effect analysis based on fuzzy and probabilistic risk analysis. Appl. Soft Comput. 2020, 96, 106689. [CrossRef]

30. Sharma, R.K.; Sharma, P. System failure behavior and maintenance decision making using, RCA, FMEA and FM. J. Qual. Maint. Eng 2010, 16, 64-88. [CrossRef] 
31. Guimarães, A.C.F.; Lapa, C.M.F.; Moreira, M.d.L. Fuzzy methodology applied to Probabilistic Safety Assessment for digital system in nuclear power plants. Nucl. Eng. Des. 2011, 241, 3967-3976. [CrossRef]

32. Pillay, A.; Wang, J. Modified failure mode and effects analysis using approximate reasoning. Reliab. Eng. Syst. Saf. 2003, 79, 69-85. [CrossRef]

33. Dias, J.; Nunes, E.; Sousa, S. Productivity Improvement of Transmission Electron Microscopes-A Case Study. Procedia Manuf. 2020, 51, 1559-1566. [CrossRef]

34. Carmignani, G. An integrated structural framework to cost-based FMECA: The priority-cost FMECA. Reliab. Eng. Syst. Saf. 2009, 94, 861-871. [CrossRef]

35. Zammori, F.; Gabbrielli, R. ANP/RPN: A multi criteria evaluation of the Risk Priority Number. Qual. Reliab. Eng. Int. 2012, 28, 85-104. [CrossRef]

36. Jang, H.A.; Lee, M.K.; Hong, S.H.; Kwon, H.M. Risk Evaluation Based on the Hierarchical Time Delay Model in FMEA. J. Korean Soc. Qual. Manag. 2016, 44, 373-388. [CrossRef]

37. Kwon, H.M.; Hong, S.H.; Lee, M.K. An expected loss model for FMEA under periodic monitoring of failure causes. J. Korean Inst. Ind. Eng. 2013, 39, 143-148.

38. Ahn, D.-G.; Cha, B.-H.; Jang, J.-S. A Case Study of Performing Process FMEA by using PFEM. J. Korean Inst. Plant Eng. 2020, 25, $15-23$.

39. Kondrateva, O.E.; Romashov, M.K.; Loktionov, O.A. Analysis of the Applicability of Key Risk Assessment Methods for Solving Problems of Reducing Accidents at Energy Facilities. In Proceedings of the 2021 3rd International Youth Conference on Radio Electronics, Electrical and Power Engineering (REEPE), Moscow, Russia, 11-13 March 2021; pp. 1-5.

40. Ali, N.; Hussain, M.; Hong, J.-E. Analyzing Safety of Collaborative Cyber-Physical Systems Considering Variability. IEEE Access 2020, 8, 162701-162713. [CrossRef]

41. Hosseini, N.; Givehchi, S.; Maknoon, R. Cost-based fire risk assessment in natural gas industry by means of fuzzy FTA and ETA. J. Loss Prev. Process Ind. 2020, 63, 104025. [CrossRef] 